\title{
KUALITAS MAYONNAISE MENGGUNAKAN SARI BELIMBING WULUH (Averrhoa Bilimbi L.) SEBAGAI PENGASAM DITINJAU DARI KESTABILAN EMULSI, DROPLET EMULSI DAN WARNA
}

\author{
The Quality of Mayonnaise Using Blimbi Starfruit Juice (Averrhoa bilimbi L.) \\ as Acidifier Based on the Emulsion Stability, Droplet of Emulsion and Color \\ Dikho Aula Prasetya ${ }^{1)}$, Herly Evanuarini ${ }^{1)}$ \\ 1) Teknologi Hasil Ternak Fakultas Peternakan, Universitas Brawijaya, Jl. Veteran Malang, Jawa Timur \\ E-mail: herlyfptub@ub.ac.id
}

Diterima 9 Maret 2019 ; diterima pasca revisi 18 Maret 2019

Layak diterbitkan 1 April 2019

\begin{abstract}
The research aims to determine the best blimbi juice (Averrhoa bilimbi L.) concentration as mayonnaise acidifier based on the emulsion stability, droplet of emulsion and color. The material used in making the mayonnaise were consisted of egg yolk, soybean oil, blimbi juice, salt, sugar, pepper and mustard. An experimental laboratory was conducted for this research by using Completely Randomized Design (CRD) with 5 treatments and 3 replications. The treatments were consisted of $P_{0}$ as control ( $0 \%$ blimbi juice), $P_{1}$ (5\% blimbi juice), $P_{2}$ (10\% blimbi juice), $P_{3}\left(15 \%\right.$ blimbi juice), and $P_{4}(20 \%$ blimbi juice). The obtained data were then analyzed by analysis of variance (ANOVA), and followed by Duncan Multiple Range Test (DMRT) to determine any differences. The results showed that blimbi juice gave a highly significant difference $(P<0.01)$ on the emulsion stability, droplet of emulsion and color of the mayonnaise. The average emulsion stabilities on P0, P1, P2, P3 and P4 were 90.30\%; 90.44\%; $80.32 \%$; 76.23\%; and $70.39 \%$ respectively. The average diameters of droplet emulsion were 1.10 - $12.67 \mu \mathrm{m}, 2.14$ - $21.69 \mu \mathrm{m}, 2.74-21.69 \mu \mathrm{m}, 3.03-36.60 \mu \mathrm{m}$, and 2.26 - $38.97 \mu \mathrm{m}$ on $\mathrm{PO}, \mathrm{P1}, \mathrm{P} 2, \mathrm{P} 3$ and $\mathrm{P} 4$, respectively. The mean L (brightness) on P0, $P 1, P 2, P 3$ and P4 were 50.12; 51.53; 52.90; 55.00; 56.61, while the $a^{*}$ (redness) were $20.35 ; 19.23 ; 18.41 ; 17.58 ; 15.76$, and $b^{*}$ (yellowness) were $35.74 ; 33.74 ; 32.21 ; 31.12$; and 29.29 , respectively. The research concluded that the usage of blimbi juice at $5 \%$ as acidifier gave the best mayonnaise emulsion stability, emulsion droplet and color.
\end{abstract}

Keywords: Mayonnaise; blimbi juice; acidifier; emulsion stability 


\begin{abstract}
ABSTRAK
Penelitian ini bertujuan untuk menentukan persentase penggunaan sari belimbing wuluh (Averrhoa bilimbi L.) terbaik sebagai pengasaman pada mayonnaise berdasarkan kestabilan emulsi, droplet emulsi dan warna. Materi yang digunakan adalah mayonnaise yang dibuat dari kuning telur sebagai emulsifier, minyak kedelai, sari belimbing wuluh (SBW) sebagai pengasam, garam, gula, lada dan mustard. Metode penelitian adalah percobaan laboratorium menggunakan Rancangan Acak Lengkap (RAL) dengan 5 perlakuan dan 3 ulangan. Perlakuan dalam penelitian ini terdiri dari $P_{0}$ sebagai kontrol tanpa penambahan $S B W, P_{1}(5 \% S B W), P_{2}(10 \% S B W), P_{3}(15 \% S B W)$, dan $P_{4}(20 \% S B W)$. Data dianalisis dengan analisis ragam (ANOVA) dan dilanjutkan dengan Uji Jarak Berganda Duncan (UJBD) jika ada perbedaan. Hasil penelitian menunjukkan bahwa penggunaan sari belimbing wuluh memberikan perbedaan yang sangat nyata $(P<0,01)$ pada kestabilan emulsi, droplet emulsi dan warna. Hasil rata-rata pada kestabilan emulsi adalah 90,30\%; 90,44\%; 80,32\%; 76,23\%; 70,39\%. Rata-rata diameter droplet emulsi mayonnaise adalah 1,10-12,67 $\mu \mathrm{m}, 2,14-21,69 \mu \mathrm{m}, 2,74-21,69 \mu \mathrm{m}, 3,03-36,60 \mu \mathrm{m}, 2,26-38,97 \mu \mathrm{m}$. Rata-rata warna $P_{0}, P_{1}, P_{2}, P_{3}$ dan $P_{4}$ pada warna Lightness (kecerahan) adalah 50,12; 51,53; 52,90; 55,00; 56,61, pada warna a* (kemerahan) adalah 20,35; 19.23; 18.41; 17.58; 15,76, dan warna $b *$ (kekuningan) 35,74; 33,74; 32,21; 31,12; 29,29. Penelitian ini menyimpulkan bahwa penggunaan 5\% sari belimbing wuluh pada pembuatan mayonnaise menghasilkan mayonnaise terbaik berdasarkan kestabilan emulsi, droplet emulsi dan warna.
\end{abstract}

Kata kunci: Mayonnaise; sari belimbing wuluh; pengasam; kestabilan emulsi

\section{PENDAHULUAN}

Belimbing wuluh (Averrhoa bilimbi L.) adalah buah yang dapat digunakan untuk keperluan hidup masyarakat mulai dari bunga, daun dan buah. Buah belimbing wuluh memiliki warna hijau dan mempunyai sisa kelopak bunga diujung buahnya. Ketersediaan belimbing wuluh melimpah dan mudah dijumpai. Kandungan senyawa kimia yang bermanfaat pada belimbing wuluh diantaranya adalah saponin dalam bentuk triterpene, flavonoid, luteolin dan epigenin berpotensi sebagai antihiperglikemia, antihiperlipidemia dan antihipertensi. Belimbing wuluh digunakan sebagai bumbu masak, sirup, penyedap pada makanan dan ramuan herbal.
Belimbing wuluh dapat mengobati batuk rejan, sariawan, jerawat, gigi berlubang, gangguan fungsi pencernaan, kelumpuhan, gusi berdarah dan tekanan darah tinggi (Parikesit, 2011).

Belimbing wuluh dapat digunakan sebagai alternatif pengasam alami karena memiliki asam organik yang tinggi. Belimbing wuluh sering digunakan sebagai pengasam alami dalam pembuatan makanan. Air perasan belimbing wuluh merupakan bahan yang bersifat asam dengan pH 2,3 (Lestari dkk., 2011). Mayonnaise yang beredar dipasaran menggunakan asam sintetis seperti vinegar maupun cuka apel. Vinegar memiliki $\mathrm{pH} 2$ (Johnston and Gaas, 2006) dan cuka apel meiliki pH 3,1 (Atro dkk., 2015).

\footnotetext{
*Corresponding author:

Herly Evanuarini

Email: herlyfptub@ub.ac.id

Teknologi Hasil Ternak Fakultas Peternakan, Universitas Brawijaya. Jl. Veteran, Malang, Jawa Timur, Indonesia, 65145
}

How to cite:

Prasetya, D. A., \& Evanuarini, H. (2019). Kualitas Mayonnaise Menggunakan Sari Belimbing Wuluh (Averrhoa Bilimbi L.) Sebagai Pengasam Ditinjau dari Kestabilan Emulsi, Droplet Emulsi dan Warna. Jurnal Ilmu dan Teknologi Hasil Ternak, 14 (1), 20-29 
Vinegar merupakan asam sintetis yang ketika dikonsumsi secara berlebih dapat memicu penyakit. Pengasam alami diperlukan dalam pembuatan mayonnaise sebagai salah satu pembentuk emulsi pada mayonnaise. Mayonnaise merupakan saus populer yang diolah dengan bahan utamanya berasal dari kuning telur dimana lesitin telur berperan sebagai pengemulsi dan dicampur dengan bahan-bahan seperti minyak nabati, vinegar serta bahan tambahan lainnya. Berdasarkan hasil penelitian Agustin dan Putri (2014) menunjukkan bahwa perlakuan komposisi belimbing wuluh berbanding air dan perbedaan konsentrasi berpengaruh nyata terhadap total asam, viskositas, nilai $\mathrm{pH}$ dan vitamin C. Menurut penelitian Prahadi dkk. (2015) bahwa penambahan sari belimbing wuluh (Averrhoa bilimbi L.) dapat digunakan sebagai pengasam alami karena memiliki kandungan asam organik yang tinggi, khususnya asam sitrat yang mencapai 92-133 meq asam dalam setiap $100 \mathrm{~g}$ padatan belimbing wuluh. Berdasarkan hal tersebut perlu dilakukan penelitian dengan menggunakan sari buah belimbing sebagai pengasam alami yang digunakan dalam pembuatan mayonnaise diharapkan mampu meningkatkan added value dan meningkatkan kualitas mayonnaise ditinjau dari kestabilan emulsi, droplet emulsi dan warna.

\section{MATERI DAN METODE}

Materi dalam penelitian ini terdiri dari mayonnaise yang dibuat dari minyak kedelai (soybean oil) dan sari belimbing wuluh (SBW) sebagai pengasam. Kuning telur ayam sebagai emulsifier, vinegar, mustard, lada bubuk, gula, garam. Pembuatan mayonnaise menggunakan peralatan yang terdiri dari hand mixer, timbangan analitik, blender, kain saring, egg separator, beaker glass ukuran $20 \mathrm{ml}$ dan $50 \mathrm{ml}$, gelas ukur, baskom bulat, solet dan sendok. Peralatan yang digunakan untuk analisis diantaranya adalah tabung reaksi, Mikroskop Olympus Bx 40 dengan perbesaran 400x dan kamera Nikon Eclipse E100 serta color reader. Metode penelitian yang digunakan adalah percobaan laboratorium menggunakan Rancangan Acak Lengkap (RAL) dengan 5 perlakuan dan 3 ulangan. Perlakuan yang dilakukan diantaranya:

$\mathrm{P}_{0}=$ Tanpa penggunaan SBW

$\mathrm{P}_{1}=$ Penggunaan $5 \% \mathrm{SBW}$

$\mathrm{P}_{2}=$ Penggunaan $10 \%$ SBW

$\mathrm{P}_{3}=$ Penggunaan $15 \% \mathrm{SBW}$

$\mathrm{P}_{4}=$ Penggunaan $20 \%$ SBW

\section{Prosedur Penelitian}

Penelitian diawali dengan pembuatan sari belimbing wuluh, yaitu buah belimbing wuluh dicuci dan dipotong menjadi 2 bagian setelah itu diblender, disaring menggunakan alat saring dan ditampung dan diendapkan.Prosedur dari pembuatan mayonnaise dengan menggunakan SBW sebagai pengasam yaitu dipilih telur ayam segar umur sehari, dipisahkan kuning telur dengan putih telur dengan egg separator. Kuning telur dipasteurisasi kemudian dicampur gula, garam, bubuk lada putih dan mustard dengan menggunakan mixer 1500 rpm selama 1 menit. Ditambahkan kuning telur dan minyak kedelai sedikit demi sedikit, secara bergantian dengan sari belimbing wuluh sesuai perlakuan. Adonan kemudian dihomogenkan dan disimpan dalam suhu ruang selama 24 jam.

\section{Variabel Penelitian}

Variabel yang diamati pada penelitian ini adalah pengujian kestabilan emulsi menggunakan metode stability rating menurut Evanuarini, dkk. (2016) :

1. Diambil sampel mayonnaise sebanyak $10 \mathrm{ml}$ dan masukkan ke tabung sentrifuse

2. Disentrifugasi selama 15-20 menit

3. Diukur volume minyak yang terpisah

4. Daya emulsi dihitung dari persentase volume minyak yang terpisah terhadap volume sampel dengan rumus :

Sampel mayonnaise - minyak terpisah Sampel mayonnaise 
Prosedur pengujian droplet emulsi dilakukan dengan pengamatan globula terkecil dan terbesar menggunakan Mikroskop Olympus Bx 40 menurut Evanuarini dkk. (2016) bahwa uji mikroskopis droplet emulsi dapat dilakukan dengan mengoleskan sedikit mayonnaise diatas objek glass dan diamati menggunakan Mikroskop Olympus Bx 40 dan kamera Nikon Eclipse E100 dengan perbesaran 400x. Kemudian dicari globulaglobula yang terkecil dan terbesar dan diukur diameter globula terbesar dan terkecil. Pengujian warna dilakukan menggunakan color reader. Sampel mayonnaise ditempatkan ke dalam cawan petri agar mendapatkan permukaan yang lebih luas.

1. Cawan petri dilapisi dengan plastik bening, kemudian alat color reader ditempelkan di permukaan mayonnaise.

2. Dinyalakan alat color reader dan dilakukan pengukuran color reader dengan menekan tombol start.

3. Mendapatkan nilai $\mathrm{L}, \mathrm{a}^{*}$, dan $\mathrm{b}^{*}$ kemudian dilakukan pengulangan 3 kali disetiap perlakuan. Nilai warna yang diambil adalah nilai L, a*, dan $b^{*}$ sebagai satu kesatuan. Nilai L, menyatakan tingkat kecerahan, mulai 0 untuk warna hitam dan 100 untuk warna putih. Nilai $a^{*}$ menyatakan warna merah untuk 0 hingga 100, dan warna hijau untuk nilai 0 hingga -80 . Nilai $b^{*}$ menyatakan warna kuning untuk nilai 0 hingga 70 dan warna biru untuk nilai 0 hingga -70 .

\section{Analisis Data}

Data yang diperoleh dianalisis dengan analisis ragam (ANOVA). Jika terdapat perbedaan pengaruh maka dilanjutkan dengan Uji Jarak Berganda Duncan. Adapun model linier Rancangan Acak Lengkap (RAL) sebagai berikut:

$$
Y \mathbf{i j}=\mu+\tau \mathbf{i}+\varepsilon \mathbf{i j}
$$

Keterangan:

$$
\begin{aligned}
\mathrm{i} & =\text { perlakuan } \\
\mathrm{j} & =\text { ulangan } \mathrm{i}, \mathrm{j}=1,2,3, \ldots, \mathrm{n} \\
\mathrm{Yij} & =\text { pengamatan pada perlakuan ke- } \mathrm{i} \\
& \text { ulangan ke- } \mathrm{j} \mu=\text { rataan umum } \\
\tau \mathrm{i} & =\text { pengaruh perlakuan ke- } \mathrm{i} \\
\mathrm{cij} & = \\
& \text { galat percobaan perlakuan ke-i } \\
& \text { ulangan ke- } \mathrm{j}
\end{aligned}
$$

\section{HASIL DAN PEMBAHASAN}

\section{Pengaruh Penggunaaan Sari Belimbing Wuluh terhadap Kestabilan Emulsi Mayonnaise}

Hasil analisis menunjukkan bahwa penggunaan sari belimbing wuluh dengan persentase yang berbeda memberikan pengaruh yang sangat nyata $(\mathrm{P}<0,01)$ terhadap kestabilan emulsi mayonnaise. Nilai rataan kestabilan emulsi mayonnaise dengan penggunaan sari belimbing wuluh dapat dilihat pada Tabel 1.

Tabel 1. Rata-Rata Kestabilan Emulsi (\%) Mayonnaise

\begin{tabular}{cc}
\hline Perlakuan & Kestabilan Emulsi \\
\hline P0 & $90,30 \pm 0,18^{\mathrm{d}}$ \\
P1 & $90,44 \pm 0,08^{\mathrm{d}}$ \\
P2 & $80,32 \pm 0,17^{\mathrm{c}}$ \\
P3 & $76,23 \pm 0,09^{\mathrm{b}}$ \\
P4 & $70,39 \pm 0,23^{\mathrm{a}}$ \\
\hline Keterangan: ${ }^{\text {a,b,c,d,e }}$ Superskrip yang berbeda \\
\multicolumn{2}{c}{ pada kolom yang sama } \\
\multicolumn{3}{c}{ menunjukkan perbedaan }
\end{tabular}

Nilai rataan pada kestabilan emulsi mayonnaise yaitu berkisar antara 70,3990,44 . Penggunaan sari belimbing wuluh yang meningkat akan menurunkan kestabilan emulsi pada mayonnaise. Kestabilan emulsi tertinggi ditunjukkan P1 yaitu 90,44 dan terendah ditunjukkan pada P4 yaitu 70,39. Kestabilan emulsi disebabkan oleh perbandingan antara fase minyak dan fase air. 
Penggunaan minyak yang lebih tinggi serta penambahan thickener mampu meningkatkan kestabilan emulsi, berbeda dengan penggunaan sari belimbing wuluh yang merupakan fase air. Fase air yang tinggi pada mayonnaise dapat menurunkan kestabilan emulsi dikarenakan belimbing wuluh memiliki kandungan air yang tinggi. Evanuarini dkk., (2016) menyatakan jika fase air dengan menggunakan tepung dan kefir yang lebih sedikit mampu meningkatkan kestabilan emulsi. Penambahan kefir melebihi $30 \%$ akan meningkatkan fase air sehingga dapat menurunkan kestabilan emulsi.

Mutiah (2002) menyatakan penggunaan minyak yang lebih tinggi dapat meningkatkan kestabilan emulsi. Kestabilan emulsi dipengaruhi keseimbangan proporsi antara protein dan air. Jika jumlah protein tidak sebanding dengan banyaknya jumlah air, maka dapat menyebabkan memisahnya air karena protein tidak mampu mengikat air yang jumlahnya cukup tinggi. Hal tersebut menyebabkan rendahnya kestabilan emulsi.

\section{Pengaruh Penggunaan Sari Belimbing Wuluh terhadap Droplet Emulsi Mayonnaise}

Pengamatan secara mikroskopik droplet emulsi mayonnaise dilakukan dengan menggunakan Mikroskop Olympus Bx 40 dan kamera Nikon Eclipse E100. Perbedaan persentase sari belimbing wuluh akan menghasilkan droplet emulsi yang berbeda. Droplet emulsi mayonnaise disajikan pada Gambar 1 .

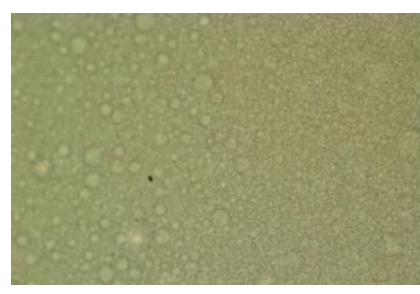

$\mathrm{P}_{0}=$ Tanpa penggunaan SBW

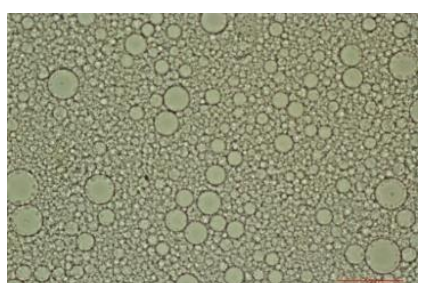

$\mathrm{P}_{1}=$ Penggunaan SBW 5\%

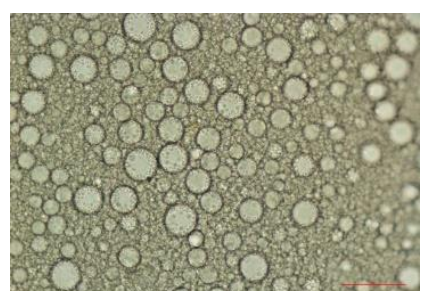

$\mathrm{P}_{2}=$ Penggunaan SBW $10 \%$

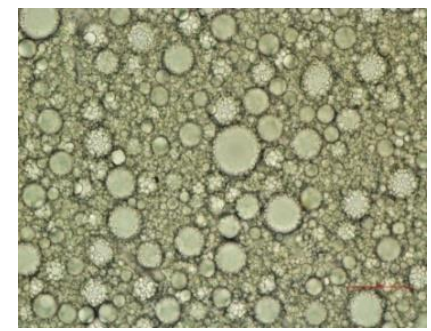

$\mathrm{P}_{3}=$ Penggunaan SBW $15 \%$

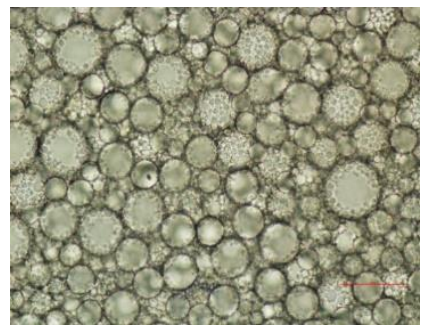

$\mathrm{P}_{4}=$ Penggunaan SBW 20\%

Gambar 1. Droplet emulsi mayonnaise dengan penggunaan SBW dengan perbesaran 400x

Gambar droplet emulsi diatas menunjukkan apabila terdapat ruang-ruang kosong dan perbedaan ukuran yang disebabkan adanya konsentrasi minyak dan penggunaan sari belimbing wuluh yang berbeda. Droplet emulsi $\mathrm{P}_{0}$ (kontrol) ukuran globula lemak yang terlihat berukuran kecil dan tersusun sangat rapat, droplet emulsi $\mathrm{P}_{1}(5 \%)$ ukuran globula lemak yang terlihat seragam, droplet emulsi
$\mathrm{P}_{2}(10 \%)$ dan $\mathrm{P}_{3}(15 \%)$ ukuran globula lemak yang terlihat cenderung renggang dan tidak seragam, sedangkan pada $\mathrm{P}_{4}$ (20\%) ukuran globula lemak yang terlihat berukuran besar. Berdasarkan gambar diatas, diameter masing-masing perlakuan yaitu $\mathrm{P}_{0}=2,10-22,67 \mu \mathrm{m}, \mathrm{P}_{1}=2,14-21,69$ $\mu \mathrm{m}, \mathrm{P}_{2}=2,74-21,69 \mu \mathrm{m}, \mathrm{P}_{3}=3,03-36,60$ $\mu \mathrm{m}, \mathrm{P}_{4}=2,26-38,97 \mu \mathrm{m}$. Pengamatan droplet emulsi pada mayonnaise ini 
bertujuan untuk mengetahui ukuran droplet dengan persentase penggunaan sari belimbing wuluh yang berbeda, dimulai dari skala yang paling kecil hingga paling tinggi. Pada perlakuan kontrol dapat disimpulkan jika ukuran droplet lebih kecil dibanding dengan perlakuan lain $\left(\mathrm{P}_{1}, \mathrm{P}_{2}, \mathrm{P}_{3}\right.$, dan $\mathrm{P}_{4}$ ). Menurut Shabbir dkk. (2015), sistem emulsi minyak air terdiri dari droplet-droplet minyak yang terdispersi dalam fase kontinyu larutan. Rivatnen (2013) menyatakan bahwa $70-80 \%$ kandungan dalam mayonnaise disusun oleh kandungan lemak.

Sistem emulsi minyak dalam air terbentuk dari fase kontinyu larutan yang didalamnya terdapat droplet-droplet minyak yang terdispersi. Hasil analisis droplet emulsi penggunaan sari belimbing wuluh pada mayonnaise menunjukkan ukuran globula yang berbeda pada setiap perlakuan. Persentase sari belimbing wuluh berpengaruh terhadap ukuran droplet, semakin meningkat penggunaan belimbing wuluh, maka droplet akan semakin besar, tidak seragam serta terdapat banyak ruang diantara droplet. Penggunaan sari belimbing wuluh yang semakin tinggi akan meningkatkan fase air dikarenakan tingginya kandungan air pada belimbing wuluh.

Hal ini menyebabkan droplet bergerak tidak teratur karena adanya ruang kosong. Menurut Biradar, et al., (2009), produk emulsi yang stabil ditandai dengan ukuran droplet yang semakin kecil. Semakin kecil ukuran droplet emulsi maka konfigurasi droplet fase terdispersi dalam medium pendispersi akan semakin teratur. Droplet dengan diameter yang kecil mempunyai kecenderungan untuk memisah lebih lambat dibandingkan dengan droplet yang berdiameter besar. Diketahui bahwa kestabilan emulsi dapat diperoleh ketika ukuran droplet emulsi adalah sebesar 0,1-1 $\mu \mathrm{m}$. Namun, menurut Fatimah dan Gugule (2011) menyatakan bahwa droplet emulsi sebesar $5 \mu \mathrm{m}$ juga dapat menunjukkan kestabilan pada viskositas emulsi yang cukup besar. Penggunaan sari belimbing wuluh dalam persentase sedikit membuat droplet berukuran kecil dan seragam yang menyebabkan mayonnaise yang dihasilkan kental. Hal ini setara dengan hasil kestabilan emulsi bahwa perlakuan $\mathrm{P}_{1}$ menghasilkan mayonnaise yang lebih viskus dibandingkan dengan perlakuan $\mathrm{P}_{2}$, $\mathrm{P}_{3}$ dan $\mathrm{P}_{4}$. Oleh karena itu, pada $\mathrm{P}_{1}$ penggunaan sari belimbing wuluh dengan persentase terendah menunjukkan jika droplet berukuran kecil dan rapat.

\section{Pengaruh Penggunaan Sari Belimbing Wuluh terhadap Warna Mayonnaise}

Warna merupakan atribut penting dalam produk pangan sebagai penanda agar mudah dikenali dan diminati oleh konsumen. Mayonnaise memiliki warna putih kekuningan hingga kuning yang disebabkan oleh salah satu komposisi penyusunnya yaitu kuning telur (Evanuarini dkk., 2016). Warna memiliki peranan yang sangat penting dalam produk pangan. Pengujian intensitas warna pada mayonnaise dapat diuji menggunakan alat Colour Reader untuk menentukan notasi L (kecerahan), $\mathrm{a}^{*}$ (kemerahan), dan $\mathrm{b}^{*}$ (kekuningan).

\section{Warna Kecerahan L}

Hasil analisis ragam menunjukkan bahwa penggunaan sari belimbing wuluh pada mayonnaise memberikan perbedaan sangat nyata $(\mathrm{P}<0,01)$ terhadap warna $\mathrm{L}$ mayonnaise. Penggunaan sari belimbing wuluh yang semakin tinggi menyebabkan nilai kecerahan mayonnaise semakin tinggi. Nilai rataan warna kecerahan L mayonnaise dengan penggunaan sari belimbing wuluh dapat dilihat pada Tabel 2.

Tabel 2 menunjukkan jika nilai terendah pada perlakuan $\mathrm{P}_{0}$ yaitu 50,12 dan nilai tertinggi didapat pada perlakuan $\mathrm{P}_{4}$ yaitu 56,62. Rata-rata nilai L (kecerahan) terus meningkat pada mayonnaise diduga karena kuning telur berwarna kuning sedangkan sari belimbing wuluh merupakan sari dari buah belimbing wuluh yang didapat dari proses blender digunakan langsung tanpa melalui tahapan lain 
sehingga akan menghasilkan sari yang berwarna terang. Lightness (kecerahan) pada suatu bahan atau produk akan meningkat jika nilai $\mathrm{L}$ mengalami peningkatan. Menurut Muzaifa (2013) jika $\mathrm{L}$ mempunyai nilai antara $1-100$, nilai $\mathrm{L}=0$ menunjukkan bahan pangan mempunyai tingkat kecerahan gelap sedangkan $\mathrm{L}=100$ menunjukkan tingkat kecerahan yang sangat cerah. Menurut Amin et al. (2014) menjelaskan jika semakin tinggi warna L, maka semakin cerah pula warna yang dihasilkan pada produk tersebut.

Tabel 2. Rata-rata nilai kecerahan L mayonnaise dengan penggunaan sari belimbing wuluh

\begin{tabular}{cc}
\hline Perlakuan & Kecerahan $\mathrm{L} \pm \mathrm{SD}$ \\
\hline $\mathrm{P}_{0}$ & $50,12 \pm 0,24^{\mathrm{a}}$ \\
$\mathrm{P}_{1}$ & $51,53 \pm 0,31^{\mathrm{b}}$ \\
$\mathrm{P}_{2}$ & $52,90 \pm 0,56^{\mathrm{c}}$ \\
$\mathrm{P}_{3}$ & $55,00 \pm 0,77^{\mathrm{d}}$ \\
$\mathrm{P}_{4}$ & $56,62 \pm 0,31^{\mathrm{e}}$ \\
\hline Keterangan: ${ }^{\mathrm{a}, \mathrm{b}, \mathrm{c}, \mathrm{d}, \mathrm{e}}$ Superskrip yang berbeda \\
\multicolumn{2}{c}{ pada kolom yang sama } \\
\multicolumn{3}{c}{ menunjukkan perbedaan } \\
\multicolumn{3}{c}{ sangat nyata $(\mathrm{P}<0,01)$}
\end{tabular}

Mayonnaise pada umumnya memiliki warna putih hingga putih kekuningan tergantung dari bahan yang dipakai untuk pembuatan mayonnaise. Penambahan mustard powder dalam pembuatan mayonnaise juga dapat memberikan pengaruh warna pada hasil akhir mayonnaise.

\section{Warna Kemerahan a*}

Nilai a* menunjukkan warna tingkat kemerahan dan kehijauan. Nilai a* positif akan menunjukkan warna merah dengan angka 0 hingga 100 , sedangkan $a^{*}$ negatif menunjukkan warna hijau dengan angka 0 hingga 80. Hasil analisis ragam menunjukkan jika penggunaan sari belimbing wuluh memberikan pengaruh perbedaan yang sangat nyata $(\mathrm{P}<0,01)$ terhadap warna kemerahan $\mathrm{a}^{*}$ pada mayonnaise. Nilai rataan warna kemerahan $a^{*}$ pada mayonnaise dengan penggunaan sari belimbing wuluh dapat dilihat pada Tabel 3.

Tabel 3 menunjukkan hasil warna kemerahan mayonnaise dengan penggunaan sari belimbing wuluh yang semakin tinggi menunjukkan penurunan pada rata-rata nilai a*. Nilai terendah pada perlakuan didapat pada $\mathrm{P}_{4}$ yaitu 15,77 dan nilai tertinggi didapat pada perlakuan $\mathrm{P} 0$ yaitu 20,35. Penurunan rata-rata nilai kemerahan $\mathrm{a}^{*}$ diduga karena penambahan persentase sari belimbing wuluh yang dapat mempengaruhi warna kemerahan pada mayonnaise.

Tabel 3. Rata-rata nilai kemerahan $a^{*}$ mayonnaise dengan penggunaan sari belimbing wuluh

\begin{tabular}{cc}
\hline Perlakuan & Kekuningan $\mathrm{b}^{*} \pm \mathrm{SD}$ \\
\hline $\mathrm{P}_{0}$ & $34,35 \pm 0,11^{\mathrm{e}}$ \\
$\mathrm{P}_{1}$ & $33,74 \pm 0,61^{\mathrm{d}}$ \\
$\mathrm{P}_{2}$ & $31,52 \pm 0,28^{\mathrm{c}}$ \\
$\mathrm{P}_{3}$ & $30,35 \pm 0,19^{\mathrm{b}}$ \\
$\mathrm{P}_{4}$ & $29,18 \pm 0,39^{\mathrm{a}}$ \\
\hline Keterangan: & a,b,c,d \\
\multicolumn{2}{c}{ pada kuperskrip yang berbeda } \\
menunjukkan yang sama \\
sangat nyata (P<0,01)
\end{tabular}

Buah belimbing wuluh mengandung senyawa triterpenoid dan flavonoid yang berperan sebagai anti bakteri dan mengandung banyak asam-asam organik (Muchtadi dkk., 2013). Kandungan flavonoid juga berperan sebagai pemberi warna kemerahan pada mayonnaise. Hasil penelitian Karlina dkk. (2013) menunjukkan jika perubahan warna pada larutan ekstrak diamati apabila timbul warna merah, kuning atau jingga, maka ekstrak positif flavonoid.

Perlakuan $\mathrm{P}_{4}$ dengan persentase sari belimbing wuluh paling tinggi menunjukkan warna semakin kearah kuning kehijauan. Hal ini dikarenakan belimbing wuluh mengandung zat pigmen klorofil. Warna hijau pada belimbing wuluh sebagaimana pada buah dan sayuran 
lainnya berhubungan dengan kandungan pigmen hijau daun yang disebut dengan klorofil (Muzaifa, 2013). Berdasarkan uraian diatas, bahwa belimbing wuluh mempunyai pigmen yang lebih dominan yaitu klorofil daripada flavonoid yang memberikan warna kuning kemerahan.

\section{Warna Kekuningan b*}

Nilai $b^{*}$ menunjukkan warna tingkat kekuningan dan kebiruan. Nilai $b^{*}$ positif akan menunjukkan warna kuning, sedangkan $b^{*}$ negatif menunjukkan warna biru. Hasil analisis ragam menunjukkan jika penggunaan sari belimbing wuluh memberikan pengaruh perbedaan yang sangat nyata $(\mathrm{P}<0,01)$ terhadap warna kekuningan $b^{*}$ pada mayonnaise. Nilai rataan warna kekuningan $b^{*}$ pada mayonnaise dengan penggunaan sari belimbing wuluh dapat dilihat pada Tabel 4.

Tabel 4. Rata-rata nilai kekuningan $b^{*}$ mayonnaise dengan penggunaan sari belimbing wuluh

\begin{tabular}{cc}
\hline Perlakuan & Kemerahan $\mathrm{a}^{*} \pm \mathrm{SD}$ \\
\hline $\mathrm{P}_{0}$ & $20,35 \pm 0,13^{\mathrm{d}}$ \\
$\mathrm{P}_{1}$ & $19,24 \pm 0,12^{\mathrm{c}}$ \\
$\mathrm{P}_{2}$ & $18,41 \pm 0,33^{\mathrm{c}}$ \\
$\mathrm{P}_{3}$ & $17,58 \pm 0,20^{\mathrm{b}}$ \\
$\mathrm{P}_{4}$ & $15,77 \pm 0,53^{\mathrm{a}}$ \\
\hline Keterangan: ${ }^{\mathrm{a}, \mathrm{b}, \mathrm{c}, \mathrm{d}, \mathrm{e}}$ Superskrip yang berbeda \\
\multicolumn{3}{c}{ pada kolom yang sama } \\
\multicolumn{3}{c}{ menunjukkan perbedaan } \\
\multicolumn{3}{c}{ sangat nyata $(\mathrm{P}<0,01)$}
\end{tabular}

Tabel 4 menunjukkan hasil warna kekuningan mayonnaise dengan penggunaan sari belimbing wuluh yang semakin tinggi menunjukkan penurunan pada rata-rata nilai $b^{*}$. Nilai tertinggi pada perlakuan $\mathrm{P}_{0}$ yaitu 34,35 dan nilai terendah didapat pada perlakuan $\mathrm{P}_{4}$ yaitu 29,18. Penurunan warna kekuningan pada mayonnaise diduga dipengaruhi oleh kuning telur dan konsentrasi penggunaan sari belimbing wuluh.
Warna kekuningan mayonnaise dapat meningkat apabila pada kuning telur terdapat vitamin A, kriptoxacin dan pigmen karotenoid, namun pada penelitian ini penggunaan kuning telur sama. Evanuarini dkk. (2016) mengatakan bahwa karotenoid yang tinggi dapat mempengaruhi kuning telur sehingga bisa digunakan sebagai pewarna dalam suatu produk pangan. Kuning telur yang berwarna kuning terang dihasilkan dari pakan yang memiliki kandungan karotenoid yang tinggi. Faktorfaktor yang dapat mempengaruhi warna kuning telur antara lain ransum dan laju produksi telur.

Laju produksi telur yang tinggi, serta kandungan xantofil dalam ransum pakan akan menyebar ke dalam kuning telur yang akan di produksi, sehingga menghasilkan warna kuning telur yang menurun (Amrullah, 2003). Perubahan warna kuning yang terdapat pada mayonnaise juga diakibatkan karena kandungan kadar air yang tinggi pada belimbing wuluh. Semakin banyak penambahan sari belimbing maka dapat menurunkan intensitas warna kekuningan. Warna mayonnaise sebelum menggunakan sari belimbing wuluh berwarna kuning pekat, namun setelah menggunakan sari belimbing wuluh akan mengalami perubahan warna menjadi putih kekuningan.

\section{KESIMPULAN}

Penelitian ini menyimpulkan bahwa penggunaan sari belimbing wuluh sebesar 5\% akan menghasilkan mayonnaise dengan karakteristik kestabilan emulsi, droplet emulsi, dan warna terbaik.

\section{DAFTAR PUSTAKA}

Agustin, F., \& Putri, W. D. R. (2013). Pembuatan jelly drink averrhoa blimbi 1. (kajian proporsi belimbing wuluh: air dan konsentrasi karagenan). Jurnal Pangan Dan Agroindustri, 2(3), 1-9. 
Amrullah, K. (2003). Nutrisi Ayam Petelur. Bogor: Lembaga Satu Gunung Budi.

AOAC. (2005). Official Methods of Analysis (18th ed.). Washington: Association of Official Analytical Chemists.

Atro, R. A., Periadnadi, P., \& Nurmiati, N. (2015). Keberadaan mikroflora alami dalam fermentasi cuka apel hijau (Malus sylvestris Mill.) kultivar granny smith. Jurnal Biologi Universitas Andalas, 4(3), 158-161. https://doi.org/10.25077/JBIOUA.4.3.\%P.2015

Biradar, S. V, Dhumal, R. S., \& Paradkar, A. R. (2009). Rheological investigation of self-emulsification process: effect of co-surfactant. Journal of Pharmacy \& Pharmaceutical Sciences: A Publication of the Canadian Society for Pharmaceutical Sciences, Societe Canadienne Des Sciences Pharmaceutiques, 12(2), 164-174.

Evanuarini, H., Nurliyani, N., Indratiningsih, I., \& Hastuti, P. (2016). Kestabilan emulsi dan karakteristik sensoris low fat mayonnaise dengan menggunakan kefir sebagai emulsifier replacer. Jurnal Ilmu Dan Teknologi Hasil Ternak, 11(2), 53-59. https://doi.org/10.21776/ub.jitek.2016.011.02.6

Fatimah, F., \& Gugule, S. (2012). Kualitas emulsi salad dressing berbahan dasar virgin coconut oil. AgriTECH, 31(2), 7985. https://doi.org/10.22146/agritech.9729

Johnston, C. S., \& Gaas, C. A. (2006). Vinegar: medicinal uses and antiglycemic effect. MedGenMed: Medscape General Medicine, 8(2), 61-83.
Karlina, C., Ibrahim, M., \& Trimulyono, G. (2013). Aktivitas antibakteri ekstrak herba krokot (Portulaca oleracea L.) terhadap Staphylococcus aureus dan Escherichia coli. LenteraBio, 2(1), 87-93.

Lestari, S., Arifin, Z., \& Ekiyantini, W. (2011). Potensi air perasan belimbing wuluh (Averrhoa bilimbi L,) sebagai bahan alternatif dentin conditioner dalam perawatan Konservasi Gigi (In-Vitro). Stomatognatic, 8(2), 90-95.

Muchtadi, T., Sugiyono, \& Ayustaningwarno, F. (2013). Ilmu Pengetahuan Bahan Pangan. Bandung: Alfabeta CV.

Mutiah. (2002). Perbandingan Mutu Mayonnaise Telur Ayam dan Mayonnaise Telur Itik (Thesis). Bogor: Institut Pertanian Bogor.

Muzaifa, M. (2013). Perubahan karakteristik fisik belimbing wuluh selama fermentasi asam sunti. Jurnal Teknologi Dan Industri Pertanian Indonesia, 5(2), 7-11. https://doi.org/10.17969/JTIPI.V5I2.1002

O'Brien, R. (2009). Fats and Oils: Formulating and Processing Applications. Boca Raton: CRC Press.

Parikesit, M. (2011). Khasiat dan Manfaat Belimbing Wuluh Obat Herbal Sepanjang Zaman Stomata. Surabaya.

Prahadi, J., Widodo, A., \& Djunaidi, H. (2015). Pengaruh penambahan sari belimbing wuluh (Averrhoa bilimbi L.) sebagai Acidifier dalam pakan terhadap penampilan produksi ayam petelur. Jurnal Nutrisi Ternak, 1(1), 10-18. 
Rivatnen, T. (2013). Ripened Cheese: The Effects of Fat Modifications on Sensory Characteristics and Fatty Acid Composition. Finlandia: University oh Helsinski.

Shabbir, M. A., Iftikhar, F., Khan, M. R., Murtaza, M. A., Saeed, M., Mahmood, S., \& Siraj, N. (2015). Effect of sesame sprouts powder on the quality and oxidative stability of mayonnaise. Journal of Food and Nutrition Research, 3(3), 138-145. https://doi.org/10.12691/JFNR-3-3-2
Su, H.-P., Lien, C.-P., Lee, T.-A., \& Ho, R.-S. (2010). Development of low-fat mayonnaise containing polysaccharide gums as functional ingredients. Journal of the Science of Food and Agriculture, 90(5), 54-63. https://doi.org/10.1002/jsfa.3888 